\title{
Neoplastic Cell
}

National Cancer Institute

\section{Source}

National Cancer Institute. Neoplastic Cell. NCI Thesaurus. Code C12922.

Cells of, or derived from, a tumor. 